Tropical Journal of Pharmaceutical Research June 2012; 11 (3): 421-428

(C) Pharmacotherapy Group, Faculty of Pharmacy, University of Benin

Benin City, 300001 Nigeria.

All rights reserved.

\title{
Effects of Ligustilide on Tumor Growth and Immune Function in Institute of Cancer Research Mice
}

\author{
Rui Long ${ }^{1,2}$, Fang Yang ${ }^{2}$, Jun-rong $\mathrm{Du}^{2 *}$, Zhong-ming Qian², Chen-yuan \\ Wang $^{2}$ and Chu Chen ${ }^{2}$ \\ ${ }^{1}$ Department of Pharmacy, the First Affiliated Hospital, Chongqing Medical University, Chongqing 400016, \\ ${ }^{2}$ Department of Pharmacology and Biopharmaceutics, Key Laboratory of Drug-Targeting and Drug Delivery System \\ of the Education Ministry, West China School of Pharmacy, Sichuan University, Chengdu 610041, China
}

\begin{abstract}
Purpose: To investigate the immunomodulatory and antitumor activities of ligustilide (LIG) extracted from Angelica sinensis in mice.

Methods: Normal and tumor-bearing Institute of Cancer Research (ICR) mice were treated p.o. with LIG (5, 20 and $80 \mathrm{mg} / \mathrm{kg} /$ day) for 7 days. In normal ICR mice, phagocytosis of peritoneal macrophages and serum hemolysin concentration were assessed by chicken red blood cell ingestion test and quantitative hemolysis of sheep red blood cells assay, respectively. Lymphocyte proliferation was determined by 3(4,5)-dimethylthiahiazo (-z-y1)-3,5-di-phenytetrazoliumromide (MTT) method. Both cytotoxic T lymphocyte (CTL) and natural killer (NK) cell activities were evaluated by lactate-dehydrogenaserelease assay. $\mathrm{H}_{22}$ ascites tumor cells were inoculated subcutaneously into ICR mice, followed by the determination of antitumor activity of $L / G$ in the $\mathrm{H}_{22}$-bearing mice.

Results: LIG significantly increased thymus and spleen index, macrophage phagocytosis, serum hemolysin concentration, spleen lymphocyte proliferation and CTL and NK cell activities in normal ICR mice, but inhibited the growth of transplantable $\mathrm{H}_{22}$ hepatoma. The effect was dose-related but not in a linear fashion. A dose of $20 \mathrm{mg} / \mathrm{kg}$ dose was more effective than 5 and $80 \mathrm{mg} / \mathrm{kg}$ doses.

Conclusion: These results suggest that LIG at $20 \mathrm{mg} / \mathrm{kg}$ has a highly boosted the immune system and tumor inhibition.
\end{abstract}

Keywords: Angelica sinensis; Ligustilide; Immunomodulation; Antitumor; $\mathrm{H}_{22}$ hepatoma cells; ICR mice 


\section{INTRODUCTION}

Cancer is a major enemy threatening man's being. Common approaches for treating cancer include surgery [1], chemotherapy [2], radiotherapy [3] and gene therapy [4].These modes usually come with side-effects. Hence, to find good cures and medicines has become increasingly become a major challemge to scientists. Immunomodulating agents can enhance or potentiate the host immune response against tumor without direct cytotoxicity to cancer cells [5].

In China, herbal remedies (i.e., specified mixtures of dried plant materials) have been utilized empirically. Chinese traditional medicines, as alternative cancer therapies, have recently attracted a great deal of attention due to their low toxicity [6,7]. Radix Angelicae Sinensis, (RAS) commonly known as "dong quai", is highly regarded in Chinese traditional medicine [8]. The major components of plant are classified into essential oil and water-soluble substances [9]. The former is believed to be its main pharmacological active components [10]. However, the essential oil consists of at least sixty-seven constituents, most of which are a great variety of lactones [9]. It has been reported that the total Angelica sinensis lactones (ASL) could significantly enhance mouse cellular immune function in vitro [11]. However, due to the complexity of the total ASL, it is unclear which components in ASL play a vital role in affecting the host immune function. In addition, the mechanisms of immunomodulatory action of ASL are not fully understood.

Ligustilide (LIG), as the main component of ASL [12], has been shown to be effective in many pathological conditions such as cerebral ischemic damage [13], primary dysmenorrhoea [14] and Alzheimer's disease [15]. However, the immunomodulatory and antitumor effects of LIG have not been reported yet. In the present work, the immunomodulatory effects of LIG, including non-specific, humoral and cellular immunity, were investigated in normal ICR mice. The antitumor activity of LIG was also studied in $\mathrm{H}_{22}$-bearing ICR mice.

\section{EXPERIMENTAL}

\section{Preparation of LIG}

Radix Angelicae Sinensis was purchased from the Danggui Cultivating Base of Good Agricultural Practice in Min Xian County, Gansu Province, China. The plant sample was collected in October, 2006, and the voucher specimen (no. 20061023) was deposited at the herbarium of West China School of Pharmacy, Sichuan University, Chengdu, China. Its identity was confirmed by Dr. Wang Chenyuan (West China School of Pharmacy, Sichuan University, Chengdu, China). LIG was prepared by a wellestablished procedure in our laboratory. Briefly, the essential oil of Angelica sinensis was extracted using a supercritical- $\mathrm{CO}_{2}$ fluid system (the granule size of plant material, 60 mu; extraction temperature, $50{ }^{\circ} \mathrm{C}$; extraction pressure, $10 \mathrm{MPa}$; extraction time, $2 \mathrm{~h}$ ). LIG was isolated from the oil by silica-gel column chromatography and identified by electron impact ionisation MS, ${ }^{1} \mathrm{H}$ NMR and ${ }^{13} \mathrm{C}$ NMR spectrometric techniques. The column was eluted with petroleum ether $\left(\mathrm{bp}, 60-90^{\circ} \mathrm{C}\right)$ and subsequently with petroleum ether-ethyl acetate (100:5). For chromatographic analyses, HPLC grade reagents and Alltima C18 column $(5 \mu \mathrm{m}, 150 \mathrm{~mm} \times 4.6 \mathrm{~mm})$ were used. LIG peak was detected at an UV absorbance wavelength of $280 \mathrm{~nm}$.

\section{Experimental animals}

Male ICR mice, weighing $20.0 \pm 2.0 \mathrm{~g}$, were provided by the experimental animal institution (Academy of Medical Sciences, Sichuan, China), and housed under normal laboratory condition ( $22 \pm 2{ }^{\circ} \mathrm{C}, 12 / 12$-h lightdark cycle) with free access to standard rodent chow and water. The experimental protocol was approved by the Institutional Animal Ethics Committee of Sichuan University, Chengdu, China (approval ref no. 
SCXK (Chuan) 2006-15), and followed the guidelines published by the National Institutes of Health [16].

\section{Effect of LIG on immune function in normal ICR mice}

The animals were randomly divided into four groups ( $n=10)$ : normal control group and 5 , 20, $80 \mathrm{mg} / \mathrm{kg}$ LIG-treated groups. LIG was diluted in $3 \%$ Tween-80 and administered p.o. for 7 days once daily. The normal control group was administered volume-matched vehicle $(0.1 \mathrm{ml} / 10 \mathrm{~g})$. On day 8 , all the animals were sacrificed by decapitation. The mice, thymus and spleen were weighed, and the thymus and spleen indices $w$ expressed as the thymus and spleen weight relative to mouse body weight.

\section{Macrophage phagocytosis assay}

Phagocytosis in the mice was performed using the methods of Lin et al [17] with some modifications. The mice were injectedi.p. with $1.0 \mathrm{ml} 2 \%$ soluble starch 3 days prior to sacrifice. On day 8 , the mice were injected i.p. with $0.5 \mathrm{ml} 5 \%$ cock red blood cells (CRBC). Thirty minutes later, the mice were sacrificed by decapitation. The peritoneal macrophages were washed by Hank's solution. After rubbing the abdomen, fluid from the abdominal cavity was collected to make two smears for each mouse. The smears were incubated at $37^{\circ} \mathrm{C}$ for $30 \mathrm{~min}$ in a wet box, washed by physiological saline solution, and then stained by Wright-Giemsa staining after quick drying. The number of CRBC ingested by 100 macrophages was counted in an optical microscope and expressed as phagocytosis index $(\mathrm{PI})$, as in Eq 1, while phagocytic efficiency index (PEI) was determined as in Eq 2.

$$
\mathrm{PI}=\mathrm{N} / \mathrm{M}
$$

where $\mathrm{N}$ is the number of total ingested $\mathrm{CRBC}$ and $\mathrm{M}$ is the number of macrophage ingesting $\mathrm{CRBC}$

$$
\left.\operatorname{PEI}(\%)=M / M_{t}\right) 100
$$

where $M$ is the number of macrophage ingesting $C R B C$ and $M_{t}$ is the number of total macrophages.

\section{Hemolysis of sheep red blood cells (QHS) assay}

QHS assay was detected using the method described by Xu and Li [18]. In brief, $0.2 \mathrm{ml}$ of $20 \%$ sheep red blood cells (SRBC) prepared in normal saline was injected into the animals, i.p., 4 days prior to the assay. On day 4 following immunization, the mice were bled and serum samples were diluted with normal saline to $1: 500$. A total of $1.0 \mathrm{ml} 5 \%$ SRBC and $1.0 \mathrm{ml} 10 \%$ guinea pig serum were mixed with $1.0 \mathrm{ml}$ diluted serum and incubated for $30 \mathrm{~min}$. After centrifugation at $2000 \mathrm{rpm}$ for $10 \mathrm{~min}$, the absorbance of the supernatant fluid was measured using a spectrophotometer (GBC Cintra 10e UVvisible spectrometer) at $540 \mathrm{~nm}$. The blank/control (in duplicate) consisted of 1.0 $\mathrm{ml} 5 \%$ SRBC, $1.0 \mathrm{ml} 10 \%$ guinea pig serum and $1.0 \mathrm{ml}$ saline solution.

\section{Mitogen-induced splenocyte proliferation}

After sacrificing them, the mice were sterilized in $75 \%$ ethanol. The spleens were extirpated on a clean bench. Under germ-free condition, single spleen cell suspension was prepared in cold phosphate buffered saline (PBS) by forcing spleen fragments through a fine nylon mesh. After washing twice in PBS, the cells were then resuspended to a concentration of $1 \times 10^{6}$ cells $/ \mathrm{ml}$ in RPMI 1640 completely cultivated liquid (HyClone, USA), using low speed centrifugation (1000 rpm for $5 \mathrm{~min})$.

Single spleen cell suspension $(100 \mu \mathrm{l})$ was placed in each well of a 96-well microplate and $100 \mu \mathrm{l}$ concanavalin A (ConA, $10 \mathrm{mg} / \mathrm{l}$ ) or lipopolysaccharides (LPS, $100 \mathrm{mg} / \mathrm{l}$ ) was added to each test well; RPMI1640 (100 $\mu \mathrm{l})$ cultivated liquid was added to the control well. Following treatment in $5 \% \mathrm{CO}_{2}$-air mixture at $37{ }^{\circ} \mathrm{C}$ for $44 \mathrm{~h}$, MTT $(5 \mathrm{~g} / \mathrm{l}, 10 \mu \mathrm{l})$ was added to each well and the plate 
incubated for another $4 \mathrm{~h}$. The supernatants were discarded. A total of $150 \mu$ limethyl sulfoxide was added to each well. The plate was then shaken until the crystals were dissolved. The absorbance, $A_{570}$, was detected on a microplate reader (Bio-Rad, Model 550, USA)

\section{Assay of cytotoxic T lymphocyte (CTL)}

The assay for cytotoxic $T$ lymphocyte (CTL) activity was performed as described previously $[7,19]$ with some modification. The splenocytes from each mouse were sensitized in vitro with mitomycin C-treated P815 mastocytoma cells at a responder/sensitizer ratio of $50: 1$ in a $5 \%$ $\mathrm{CO}_{2}$-air mixture at $37^{\circ} \mathrm{C}$ for 5 days. For the preparation of mitomycin C-treated P815 cells, cells $\left(1 \times 10^{5}\right.$ cells $\left./ \mathrm{ml}\right)$ were incubated in the dark with mitomycin $\mathrm{C}$ at a concentration of $0.25 \mu \mathrm{g} / \mathrm{ml}$ for $30 \mathrm{~min}$ at $37{ }^{\circ} \mathrm{C}$, and then the cells were washed four times. Following the sensitization phase, cultured spleen cells were harvested and resuspended in RPMI 1640 complete cultivated liquid, counted and diluted to $1 \times 10^{6}$ cells $/ \mathrm{ml}$ for the determination of CTL activity. P815 cells $\left(1 \times 10^{5}\right.$ cells $\left./ \mathrm{ml}\right)$ were co-cultured in duplicate with $100 \mu \mathrm{l}$ splenic effector cells in a 96-well microplate (cell ratio of effector: target, 10:1). After incubating for $4 \mathrm{~h}$ at $37{ }^{\circ} \mathrm{C}$, the plate was centrifuged at $1000 \mathrm{rpm} / \mathrm{min}$ for $5 \mathrm{~min}$ and the supernatant for each well $(50 \mu \mathrm{l})$ was transferred into another 96-well microplate; $100 \mu \mathrm{l}$ of lactic acid dehydrogenase substrate mixture was added to each well. After $3 \mathrm{~min}$, $50 \mu \mathrm{l}$ of $1 \mathrm{M} \mathrm{HCl}$ was added to each well to stop the reaction. Finally, a microtiter plate reader (Bio-Rad, Modal 550, USA) was used for the evaluation of changes in the absorbance at a wavelength of $490 \mathrm{~nm}$. To determine the percentage of killed target cells, Eq 3 was applied.

CTL cell activity $(\%)=(E-S) /(M-S) \times 100$

where $\mathrm{E}$ is the experimental release of LDH activity from target cells incubated in the presence of lymphocytes, $M$ the maximum release of LDH activity determined by lysing the target cells with $1 \%$ of NP-40, and S the spontaneous release of LDH activity from target cells incubated in the absence of lymphocytes.

\section{Assay of NK cells activity}

Single spleen cells suspension $\left(1 \times 10^{6}\right.$ cells $/ \mathrm{ml}, \quad 100 \mu \mathrm{l}$ ) and target cells YAC-1 $\left(1 \times 10^{5}\right.$ cells $\left./ \mathrm{ml}, 100 \mu \mathrm{l}\right)$ were placed in a $96-$ well microplate (effect: target ratio, 10:1). The cells were incubated in a $5 \% \mathrm{CO}_{2}$-air mixture at $37{ }^{\circ} \mathrm{C}$ for 4 h. Lactate dehydrogenase (LDH) activity was measured as described above.

\section{Evaluation of antitumor activity}

$\mathrm{H}_{22}$ hepatoma cells were maintained in the peritoneal cavities of ICR mice provided by the experimental animal institution (Academy of Medical Sciences, Sichuan, China).

$\mathrm{H}_{22}$ ascites tumor cells (about $5 \times 10^{6} / \mathrm{ml}$ ) were inoculated subcutaneously (s.c.) into ICR male mice. Tumor size was measured using a caliper across its longest diameter (a) and the second longest diameter (b), and its volume was calculated using Eq 4.

$V=0.5 a b^{2}$.

Treatment of the tumors was started after 7 days when the mice showed palpable tumors (minimal volume of $14 \mathrm{~mm}^{3}$ ). The inoculated mice were randomized into five groups: 5,20 , $80 \mathrm{mg} / \mathrm{kg}$ LIG treatment groups, $\mathrm{H}_{22}$-bearing mice as negative control group and cisplatintreated mice as positive control group. Cisdiaminodichloroplatin (DPP, $2 \mathrm{mg} / \mathrm{kg}$ ) was given to positive control group every week. LIG was diluted in $3 \%$ Tween-80 and administered p.o. once daily. In all cases, the tumors were measured every 3 days. Inhibition ratio (IR) was calculated using $\mathrm{Eq}$ 5.

$\operatorname{IR}(\%)=\{(\mathrm{A}-\mathrm{B}) / \mathrm{A}\} \times 100$ 
where $A$ and $B$ are the mean tumor volume of the negative control and treatment groups, respectively. All the mice were sacrificed after 15 days of treatment, when the longest diameter of tumors of control group exceeded $20 \mathrm{~mm}$.

\section{Statistical analysis}

The results were expressed as mean \pm standard deviation (SD). Statistical analysis was performed with SPSS 13.0. Analysis of variance was followed by Fisher's least significant difference test. Differences were considered to be significant when $p<0.05$.

\section{RESULTS}

\section{Effect of LIG on nonspecific immune function in normal ICR mice}

The purity of LIG was > $98 \%$ based on the total peak area obtained by HPLC analysis in this study.As shown in Table 1, treatment with LIG $(20 \mathrm{mg} / \mathrm{kg})$ produced the highest number of thymus, and also yielded the greatest spleen index, phagocytosis index (PI) and phagocytic efficiency index (PEI); 5 and $20 \mathrm{mg} / \mathrm{kg}$ doses caused a significant increase in the above parameters $(p<0.05$ and $p<0.001$, respectively). Treatment with LIG $(80 \mathrm{mg} / \mathrm{kg})$ only slightly increased thymus, spleen index and macrophage phagocytosis, but no significant increase was observed in this group.

\section{Effect of LIG on humoral immune function in normal ICR mice}

Table 1 shows that treatment with LIG (20 $\mathrm{mg} / \mathrm{kg}$ ) significantly increased hemolysin concentration in normal ICR mice $(p<0.05)$. LIG (5 or $80 \mathrm{mg} / \mathrm{kg}$ ) also increased antibody concentration in mouse serum, but the difference (compared with control) was not significant $(p>0.05)$.

\section{Effect of LIG on cellular immunity in normal ICR mice}

The effect of LIG on induced proliferation of splenic lymphocytes (induced by Con $A$ or LPS) is shown in Table 2, Con A-induced T lymphocyte proliferation was significantly increased at all LIG dose levels of $5,20,80$ $\mathrm{mg} / \mathrm{kg}(p<0.001, p<0.001$, and $p<0.001$, respectively), and the proliferation rate was 19.2, 27.6 and $10.3 \%$, respectively. LPSinduced B lymphocyte proliferation was also significantly increased $(p<0.001)$ at all LIG dose levels at the proliferation rate 16.2, 21.9 and $14.1 \%$, respectively.

Enhancement of proliferation of splenic lymphocytes by LIG suggests that this compound may also affect the generation of cell-mediated cytotoxic responses. To test this, we examined the effect of LIG on the production of antigen-specific cytotoxic $T$ lymphocytes (CTLs). The cytolytic activity of effector cells against p815 target cells was determined by lactate dehydrogenase activity assay. CTL activity increased at all three LIG doses in normal ICR mice $(p<0.001)$, as shown in Figure $1 \mathrm{~A}$.

Table 1: Effect of LIG on thymus and spleen indice, macrophage phagocytosis and serum hemolysin concentration in normal ICR mice (mean \pm S.D, $n=10$ )

\begin{tabular}{clllll}
\hline $\begin{array}{c}\text { Group } \\
(\mathbf{m g} / \mathbf{k g} / \mathbf{d})\end{array}$ & $\begin{array}{c}\text { Thymus index } \\
(\mathbf{m g} / \mathbf{g})\end{array}$ & $\begin{array}{c}\text { Spleen index } \\
(\mathbf{m g} / \mathbf{g})\end{array}$ & \multicolumn{1}{c}{ PEI (\%) } & PI & QHS A \\
\hline Control & $1.89 \pm 0.51$ & $6.09 \pm 0.62$ & $37.39 \pm 3.60$ & $1.01 \pm 0.06$ & $0.403 \pm 0.075$ \\
5 & $2.57 \pm 0.84^{*}$ & $7.12 \pm 0.87^{*}$ & $45.33 \pm 3.97^{\star *}$ & $1.07 \pm 0.09^{*}$ & $0.481 \pm 0.069$ \\
20 & $3.02 \pm 0.90^{* *}$ & $7.78 \pm 0.76^{* *}$ & $48.06 \pm 3.44^{* *}$ & $1.13 \pm 0.09^{* *}$ & $0.510 \pm 0.057^{*}$ \\
80 & $2.29 \pm 0.88$ & $6.70 \pm 1.58$ & $38.72 \pm 3.00$ & $1.04 \pm 0.07$ & $0.462 \pm 0.071$ \\
\hline
\end{tabular}

${ }^{*} p<0.05,{ }^{* *} p<0.001$, compared with control group 
Table 2: Effects of LIG on spleen lymphocyte proliferation, CTL and NK activity in normal ICR mice (mean \pm S.D, $n=10$ )

\begin{tabular}{lll}
\hline $\begin{array}{l}\text { Group ( } \\
\text { mg/kg/d) }\end{array}$ & $\begin{array}{l}\text { T Lymphocyte } \\
\text { proliferation } \\
(\%)\end{array}$ & $\begin{array}{l}\text { B Lymphocyte } \\
\text { proliferation (\%) }\end{array}$ \\
\hline Control & - & - \\
5 & $19.2 \pm 12.5^{* *}$ & $16.2 \pm 3.1^{* *}$ \\
20 & $27.6 \pm 14.1^{* *}$ & $21.9 \pm 5.8^{* *}$ \\
80 & $10.3 \pm 7.6^{*}$ & $14.1 \pm 9.8^{* *}$ \\
\hline
\end{tabular}

${ }^{*} p<0.05,{ }^{* *} p<0.001$ compared with control group.
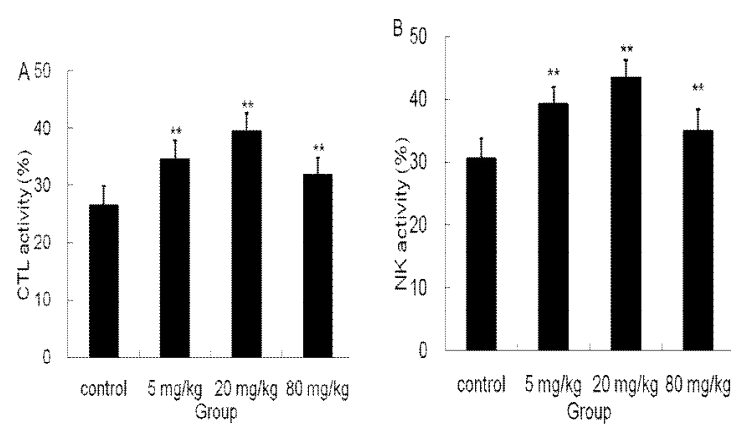

Figure 1: Effect of LIG on (A) CLT and (B) NK cell activity in normal ICR mice; ${ }^{* *} p<0.001$ compared with control group (mean $\pm S . D, n=10$ )

To investigate the effect of LIG on the development of non-specific cytotoxic cells, the cytotoxic activity of NK cells was determined by $\mathrm{LDH}$ release assay using YAC-1 as target cells. The effect of LIG on the development of NK cell-mediated cytotoxicity was significantly different from the control at all three doses $(p<0.001)$, as Figure. 1B shows.

\section{Antitumor activity of LIG in $\mathrm{H}_{22}$-bearing mice}

As shown in Figure 2, LIG significantly inhibited the growth of mouse transplanted $\mathrm{H}_{22}$ hepatoma. After 15 days treatment, the tumor inhibitory rate was $17.1,46.9$ and 27.7 $\%$ for LIG dose levels of 5,20 and $80 \mathrm{mg} / \mathrm{kg}$, respectively. LIG $(20 \mathrm{mg} / \mathrm{kg})$ exerted the highest inhibitory effect (46.9\%), close to that of DPP $(52.6 \%)$, which was the positive control.

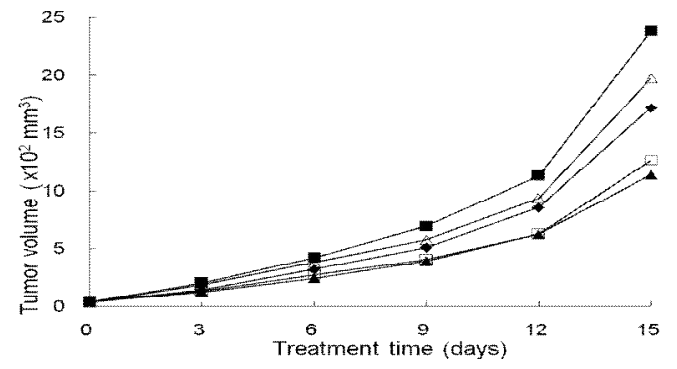

Figure 2: Antitumor activity of LIG in $\mathrm{H}_{22}$ tumorbearing ICR mice. Note: control group ( $\mathbf{\square})$, $80 \mathrm{mg} / \mathrm{kg}$ LIG group $(\triangle), 5 \mathrm{mg} / \mathrm{kg}$ LIG group $(\diamond)$, $20 \mathrm{mg} / \mathrm{kg}$ LIG group ( $\square$ ), cisplatin group $(\boldsymbol{\Lambda})$.

\section{DISCUSSION}

The relationship between the occurrence, growth and decline of tumor and immune states is a major problem in tumor immunology. The discovery and identification of new antitumor drugs to potentiate immune function has become an important goal of research in immunopharmacology and oncotherapy. This study demonstrates the favorable immunomodulatory activity and antitumor effect of LIG, a phthalide derivative from Angelica sinensis.

Protective immunity against tumor comprises of non-specific, humoral and cellular immunity. Enhancement of phagocyte function is applicable to therapy of cancer because phagocytes act as regulator and effector cells in the immune system and phagocytosis represents an indispensable step in the immunological defense system [20]. Humoral defence via antibody response is mediated by $B$ cells and other immune cells involved in antigen processing and immunization. Antigen-antibody complex can counteract toxins and defend the infection induced by the pathogen. Cell-mediated immune defense is mediated specifically by $T$ cells including cytotoxic $T$ cells. $T$ cells can kill tumors and produce many lymphocyte factors consisting of macrophage mobile factor, lymphotoxin, transfer factor and interferon, which can enhance macrophage phagocytosis and the capacity of killing target cells [21]. NK cells mediate the immediate 
killing of tumor cells and play a primary role in regulating immune responses as well [22].

In this study, we found that LIG significantly increased macrophage phagocytosis, hemolysin concentration, spleen lymphocyte proliferation, as well as CTL and NK cell activities in normal ICR mice, which suggests that LIG could enhance non-specific, humoral and cell-mediated immunity in normal mice. Based on this, it seems likely that LIG might have potential tumor therapeutic activity by enhancing the immune system.

On examining the effect of LIG on the $\mathrm{H}_{22}$ bearing ICR mice, it was found that LIG significantly inhibited the growth of mouse transplantable $\mathrm{H}_{22}$ hepatoma after treatment with LIG and the inhibitory effect of LIG (20 $\mathrm{mg} / \mathrm{kg}$ ) was close to that of the positive control, DPP (2 mg/kg).

The inhibitory effect of LIG on tumor growth as well as its immunomodulatory activity were dose-dependent, with the effect of the highest LIG $(80 \mathrm{mg} / \mathrm{kg})$ lower than that of the least dose $(5 \mathrm{mg} / \mathrm{kg})$. Thus, $20 \mathrm{mg} / \mathrm{kg}$ can be considered the optimum LIG dose to enhance host immune function and inhibit tumor growth in mice. It was reported that the key to regulating the immune function rests in the level of immune state in the body, not the level of dose. The immune level can be regulated in autoimmunity process and no effect was evident at higher doses above the limit. It was achieved by integral harmony function in which network of immuneneuroendocrine interactions was the priority [23].

\section{CONCLUSION}

The present study, to the best of our knowledge, reports for the first time the immunomodulatory and antitumor activities of LIG. The findings indicate that the antitumor activity of LIG is due to the augmentation of immune responses against tumors. Thus, the compound is a potentially attractive drug candidate for cancer therapy, possibly by combining it with chemotherapeutic agents with a view to achieving synergistically therapeutic outcome against tumors.

\section{ACKNOWLEDGEMENT}

The study was supported by Research Grants of National Key Laboratory of Chinese Medicine and Molecular Pharmacology in Shenzhen, China, and Hong Kong Polytechnic University Research Grants (A256, G-YE98, G-YX14, G-YD78, G-T616, and G-T856).

\section{REFERENCES}

1. Cummins J, McCullochfl P, ASCOT Co-operative Group. ASCOT: a comprehensive clinical database for gastro-oesophageal cancer surgery. Eur J Surg Oncol. 2001; 27(8): 709713.

2. Takiguchi $N$, Saito $N$, Nunomura $M$, Kouda K, Oda K, Furuyama N, Nakajima N. Use of 5-FU plus hyperbaric oxygen for treating malignant tumors: evaluation of antitumor effect and measurement of 5-FU in individual organs. Cancer Chemother Pharmacol. 2001; 47(1): 11-14.

3. Schmitt Gl, Wambersie A. Review of the clinical results of fast neutron therapy. Radiother Oncol. 2001; 17(1): 47-56.

4. Rots MG, Curiel DT, Gerritsen WR, Haisma HJ. Targeted cancer gene therapy: the flexibility of adenoviral gene therapy vectors. J Control Release. 2003; 87(1-3): 159-165.

5. Kim HM, Han SB, Oh GT, Kim YH, Hong DH, Yoo ID. Stimulation of humoral and cell mediated immunity by polysaccharide from mushroom phellinus linteus. Int J Immunopharmacol. 1996; 18(5): 295-303.

6. Fujimiya $Y$, Suzuki Y, Katakura R, Ebina T. Tumorspecific cytocidal and immunopotentiating effects of relatively low molecular weight products derived from the basidiomycete, Agaricus blazei Murill. Anticancer Res. 1999; 19(1A): 113-118.

7. Zhang $W Y$, Wang $Y$, Hou $Y Y$. Effects of Chinese medicinal fungus water extract on tumor metastasis and some parameters of immune function. Int Immunopharmacol. 2004; 4(3): 461468.

8. Sun YL, Tang J, Gu XH, Li DY. Water-soluble polysaccharides from Angelica sinensis (Oliv.)Diels: Preparation, characterization and bioactivity. Int J Biol Macromol. 2005; 36(5): 283-289.

9. Huang LF, Li BY, Liang YZ, Guo FQ, Wang YL. Application of combined approach to analyze the 
constituents of essential oil from Dong Quai. Anal Bioanal Chem. 2004; 378(2): 510-517.

10. Huang $W H$, Song $C Q$. Research progresses in the chemistry and pharmacology of Angelica sinensis (Oliv.) Diel. Zhongguo Zhong yao Za zhi. 2001; 26(3): 147-151.

11. Kuang $X, D u$ JR, Chen YS., Wang J, Wang YN. Protective effect of Z-ligustilide against amyloid beta-induced neurotoxicity is associated with decreased pro-inflammatory markers in rat brains. Pharmacol Biochem Behav. 2009; 92(4): 635-641.

12. Li GS, Ma CJ, Li XY, Liu K. Studies on the Stability of Ligustilide and the Analysis of Its Isomerized Products by GC-MS. Zhong Cao Yao. 2000; 31(6): 405-407.

13. Zhang L, Du JR, Wang J, Yu DK, Chen YS, He Y, Wang CY. Z-ligustilide extracted from Radix Angelica Sinensis decreased platelet aggregation induced by ADP ex vivo and arteriovenous shunt thrombosis in vivo in rats. Yakugaku Zasshi. 2009; 129(7): 855-859.

14. Du JR, Bai B, Kuang $X, Y u$ Y., Wang $C Y, K e Y, X u$ YJ, Tzang AH, Qian ZM. Ligustilide inhibits spontaneous and agonists- or $K^{+}$depolarizationinduced contraction of rat uterus. $J$ Ethnopharmacol. 2006; 108(1): 54-58.

15. Kuang $X, D u$ JR, Chen YS., Wang J, Wang YN. Protective effect of Z-ligustilide against amyloid beta-induced neurotoxicity is associated with decreased pro-inflammatory markers in rat brains. Pharmacol Biochem Behav. 2009; 92(4): 635-641.

16. National Institutes Health, USA. Public health service policy on human care and use of laboratory animals. 2002.

17. Lin $P Y$, Feng ZM, Pan JQ, Zhang $D$, Xiao $L Y$. Effects of artesunate on immune function in mice. Zhongguo Yao Li Xue Bao. 1995; 16(5): 441-444

18. $X u X Y, L i Y, X u$ J. A modified humoral immune assay method, a method of hemolysin determination. Yao Xue Xue Bao. 1979; 14(7): 443-446.

19. Auttachoat W, Chitsomboon B, Peachee VL, Guo, T.L, White KL J. Immunomodulation by Dok Din Daeng (Aeginetia indica Roxb.) extracts in female B6C3F1 mice (I): Stimulation of T cells. Int Immunopharmacol. 2004; 4(10): 1367-1379.

20. Stuelp-Campelo $P M$, de Oliveira $M B$, Leão $A M$, Carbonero ER, Gorin PA., lacomini M. Effect of a soluble a-d-glucan from the lichenized fungus Ramalina celastri on macrophage activity. Int Immunopharmacol. 2002; 2(5): 691-698.

21. Han SB, Kim YH, Lee CW, Park SM, Lee HY, Ahn KS, Kim I, Kim HM. Characteristic immunostimulation by angelan isolated from Angelicagigas Nakai. Immunopharmacol. 1998; 40(1): 39-48.

22. Kodama N, Komuta K, Sakai N, Nanba H. Effects of $D$-Fraction, a polysaccharide from Grifola frondosa on tumor growth involve activation of NK cells. Biol Pharm Bull. 2002; 25(12): 16471650.

23. Besedovsky HO, Sorkin E. Network of immuneneuroendocrine interactions. Clin Exp Immunol. 1977; 27(1): 1-12. 